\title{
Unfinished Revolution: The Arab Spring at the Crossroads
}

\author{
Osaretin Idahosa Ph.D
}

And

Daniel Tonwe Ph.D

Doi:10.5296/ijhrs.v3i4.4519

URL: http://dx.doi.org/10.5296/ijhrs.v3i4.4519

\begin{abstract}
Currently, the Arab world is going through a critical phase of its collective existence as the entire region is under the grip of a revolutionary fervour. The consequences have both political and economic ramifications. Hitherto, totalitarian and dictatorial regimes in the region had not only tightly controlled the levers of power through political threats and manipulations but had also exploited whatever economic benefits which were available therein. This was accentuated by poor economic performance, unemployment, corruption and inequality that acted as catalysts for a general revolt. This gave birth to what is presently dubbed "Arad Spring". Within months of the self immolation of Mohammed Buazizi, Tunisian President, Zine Al-Abidin Ben Ali who had ruled the country for 23years, fled the country. Also in Egypt, the wave of protests swept off President Hosni Mubarak after 29years in office. Despise the regime change in both countries; the political institutions that supported the old order were left intact. As such, the benefactors of the spring were not the masses but the members of the elites that were either supportive of the toppled regimes or their antagonists who used it to secure the much needed elusive political powers. This study is a survey of the countries where the authoritarian regimes have been replaced as a result of the Arab revolts, specifically; Egypt and Tunisia are the case studies. The emphasis is on how unmet expectations and unrealized goals have tended to derail the realization of the initial dreams of the citizenry in these countries.
\end{abstract}

\section{Introduction}

A lot has happened in and to North Africa and the Middle East since the self-immolation of Muhammad Buazizi in Tunisia on December 10 2010. The wave of popular protests that convulsed this sub-region of the world, overthrowing long-ruling dictators, have added to its already complex, variegate and complicated politics. While it is true that the Arab Spring was unexpected in some quarters the mass protests that spread across the entire Arab world had their origins not in January of the same year but over decades earlier. When the uprising started the anger fueling it was not new. It had a prolonged period of incubation, exploding at times, but never before in such widespread and sustained fury. To this effect, the grievances 
against the leadership of these countries were driven by economic, social, historical, political and personal factors. Poverty, youth mass unemployment, social exclusion and political alienation combined to create the objective conditions for the revolts.

However, with the collapse of long- lived dictator in Tunisia and Egypt (Ben Ali and Hosni Mubarak) in early 2011, it is imperative to investigate the level of success of what is characteristically dubbed Arab spring. The question to ask therefore is: who were the beneficiaries of the revolution? To a number of academics, one common answer has been both the constitutional referendum in the aftermath of regime change in Tunisia and the military transition in Egypt excluded the prime movers of the revolutions (Hess, 2013). Also, there has been repeated reincarnation of protests throughout the entire sub-region. While it is true that what took place in 2011 was undisputedly a spectacular act of civil disobedience against long-standing autocrats, the revolution were not decisive as the strides towards freedom, democracy and pluralism is still far from realized. The Arab uprising tended to have removed one layer of the complex challenge confronting the Arab world, but the fundamental issue remained insulated. The social drivers of the unrest in Tunisia and Egypt were: high level of youth unemployment, widening socio-economic inequality, endemic official corruption and of course, resilience of authoritarian regimes. It was the collective desire of the people to redress these imbalances that led them to take their common destiny in their hands. Today, there are mounting fears that this mission has been derailed. The next sets of questions to ask are: what were the causal factors of the Arab Spring? Where these factors sufficiently addressed by the outcome of the revolution? Were there other intervening variables that were unseen by the prosecutors of the revolution? Could there have been different results if otherwise? This paper intends to provide answers to these questions and establish their relevance to the assessment of the Arab Spring.

\section{Establishing causality}

At the glance, the Arab spring appeared diffuse in term of inertia and momentum. A closer look however, would reveal that bottom-up factors drove the Middle Eastern discontent. Perhaps, what triggered -off the social eruptions had its roots in long -standing deprivations of the citizenry by the leadership. This was manifested in terms of socio-economic inequality, official corruption, high rate of youth unemployment and the diffusion of modern communication technologies. In every society, the primacy of economic performances is vested with endless possibilities. A vibrant economy engenders not only growth and development but also internal cohesion. In the absence of this prerequisite, poverty and mass unemployment (especially amongst the youth) create the objective conditions for revolts. In Egypt at as well as Tunisia, poverty and unemployment remain important problems. Over the past three decades, the economies of the two states have grown at a relatively sluggish rate with Egypt $(5.10 \%)$ and Tunisia $(4.52 \%)$ respectively (World Bank, 2010). Over the years, there had been in both countries a deepening public anger over political and economic grievances Growing popular frustration led to what is commonly known as Black Thursday disturbances in Tunisia in 1978 and was later re-enacted as widespread public riot in late 1983 and early 1984 (Entelis and Tessler, 1986)

While it is true that economic factors were among the social drivers of the revolts in 
Egypt and Tunisia, the characters of the regimes in the two countries played a significant role. In autocracies where legitimacy is far- fetched, the maintenance of internal cohesion is dependent not only on economic performances but also on the general support for the regime. The political culture in Egypt and Tunisia since the 1970s tended to have legitimized the personal rule of Ben Ali and Hosni Mubarak respectively .However, in the wake of a severe economic crises as evident in the global financial meltdown in 2008, internal discontent was consummated in these two countries. Thus, complicated economic fortunes accentuated by dire socio-political crises helped terminate the regimes of Hosni Mubarak in Egypt and Ben Ali in Tunisia. In terms of demographics, the dilemma in both countries is population. The population density in Egypt is one of the highest in the world. Tunisia had a population growth rate of about $3 \%$ a year as far back as the twilight of the twentieth century (Long and Reich, 2008). Poor socio-economic conditions in the countryside drive hundreds of thousands of people (mostly youths) into urban slums in Egypt and Tunisia. Also, high fertility rates have produced substantial youth bulged of about $62.7 \%$ in Egypt and $56.1 \%$ in Tunisia in the first decades of the twenty-four century (Hess, 2013). Complimenting the above is a large, educated youth cohort who was frustrated with the prevailing conditions at home. The official unemployment rates in Egypt and Tunisia in 2005 were averaged at $11.2 \%$ and 14.25. A as result of these huge rates of unemployment, many youths frustrated with the prevailing political and economic conditions took solace in plotting and organizing anti-regime collective actions.

Even before the turn of the last century, there had been series of contestation around the distribution of available resource in Egypt and Tunisia. The gap between the rich and poor, though not as large as in some development countries, has increased considerable over the year. The situation on ground approximates a two-class system; a very rich upper class and very lower class, with the latter vastly larger than the former. Even among the poor, poverty seemed to have grown with an increase divided between regular employed workers who are protected by trade unions and social legislation and those who work on an intermittent or seasonal bases, in the internal sector, or perhaps not at all (Long and Rich, 2008) in turns of followership, the strike and disturbance of 2011 saw members of the former group, whose material conditional were deterioration, feel powerless as the nations' economic burden was not distributed equitably. This frustrated mass formed the bulk of the drivers of the Arab Spring. The situation described above bespeaks of a widening socio-economic inequality that helped to drive the protests in Egypt and Tunisia (Knickmeyer, 2011). Accordingly, the materials conditions of the poor and alienated working class contrasted with the privileges enjoyed by those connected with the regimes in both countries. This motivated them to join ranks with educated youths to demand for regime change. Prior to the Arab Spring, popular uprising in both countries were centered on the regimes inability to curtail rising food prices or provide other basic grievances (Ottway and Hamzawy, 2011). Accordingly:

In Egypt more than 1000 protest actions took place from 1998 to 2004. After the implementation of economic liberalization policies, this cut social services and government spending as well as increased protests by 200 percent, amounting to 250 in 
2004 alone. In April 2005, as many as half-million Egyptians participated in more than 400 actions, including a general strike centering in al-mahalla Al-Kubra and involving tens of thousands of states workers, youth activists and professionals. Meanwhile in Tunisia, materially aggrieved citizens organized collective actions against a mining company in 2008, which soon came to involve protesters demonstrating against rising inflation and unemployment in order parts of the country (Ottaway and Hamzaway, 2011: 2-6).

Since the beginning of the new millennium data on socio-economic inequality suggest that the gap between the rich and poor in both countries has widened even further. According to Hess (2013), in 2001, Egypt's Gini Index for the distribution of family inequality was reported at 34.4 ( $70^{\text {th }}$ most unequal of 136 countries), Whereas Tunisia's was estimated at 40.0 ( $61^{\text {st }}$ most unequal) in 2005. Thus, frustration over extreme inequality which has percolated upward from the lowest range in both societies into the middle class contributed immensely to the crises.

To analysts and observes alike, officially corruption is at the heart of the Arab Spring .According to Levey (2011), officially corruption is "Key grievances driving protest throughout the Arab world". This reality in further reinforced by the trials of Hosni Mubarak and Ben Ali and their cronies whose practices ranged from money laundering to drug trafficking while in office in the Corruption Perceptions Index (CPI) of 2010, Egypt and Tunisia were scored at 3.1 and 4.3, respectively. This placed them at the ranks of $78^{\text {th }}$ and $59^{\text {th }}$ overall (Transparency International 2011). There is indeed a mutual inclusiveness between the impact of corruption on both economies and the "anger-venting" mass incidents that have revealed the groundswell of frustration against corrupt and abusive government officials in Egypt and Tunisia. This, of course presupposes the pre-existence of structural weakness of the regimes which the drivers of the rebellion exploited. The regimes in Egypt and Tunisia were slowly ebbed off by chronic and pervasive corruption (predominately at the official level) and the lack of effective institutional mechanism for maintaining long term internal cohesion.

\section{On Revolution}

In different academic cycles, there has been a lot of contestations on whether the Arab Spring was really a revolution or not. Despite been essentially marked by regime change, the mass protests that engulfed the Middle East did not produce the much anticipated transformation of society by the protagonists. If indeed, we conceded that it had a semblance of a revolution, was it social or political? For it is to be accepted as social revolution, it should have produced attitudinal change at least. However, the ideological divide between the secularists and Islamists on the other hand and their perceptions on how to build on the initial gains of the revolt is at the heart of the problematic; especially in Egypt. This tends to undermine the concerns of the common people expressed as social rights namely: education, employment and health care. Thus, there are mounting fears about a potential religious take over following 
the Iranian model. The extent to which sharia laws can govern public life in the new regimes in Egypt and Tunisia will surely be the litmus test of the unfolding events in these countries. Nonetheless, a truly secular regime total absolved from the influence of religion will do more harm than good in the ensuring context. In the aftermath of the spring, to envisage Egypt and Tunisia governed unyieldingly by the principles of Sharia without the effort of contextualization and interpretation would result in a religious orthodoxy. After all, history has taught us that the citizens abhor all forms of coercion, be it religious or ideological. Perhaps what is urgently needed is to build a synergy between religion and politics in an atmosphere of social justice.

In a political revolution, not only is the regime replaced but also its institutions. Depending on its density, the old property relations could be overturned or not. Indeed a revolution is not carried out at the behest of the political elites, but rather by ordinary people when especially, they are dissatisfied with the old order. Within Marxist theory, Karl Max and Friedrich Engels in about 1850 established the use of the term Permanent Revolution which has since become mostly associated with Leon Trotsky. Although the use of the term by different theorists is not identical, Marx used it to describe the strategy of a revolution of any class. The call was on the revolutionary class to continue to pursue its class interest independently and without compromise; regardless of the overtures or allures of political alliances and despite the political dominance of opposition section of society (Engels, 1845).

Trotsky evolved the concept of 'Permanent Revolution' to explain how socialist revolutions could occur in a society that has not achieved advance capitalism. the central argument here rests on two pillars : (a) that the bourgeoisie in late - developing capitalist countries are not capable to develop productive forces as did the advance capitalist societies with full - blown industrial proletariat (b) that the proletariat in collaboration with the peasantry can and most seize social, economy and political power(Trotsky, 1931). The thrust of Trotsky's theory was that in Russia, the bourgeoisie would not be able to see through a thorough revolution that would guarantee political democracy and solve the land question. He therefore argued that future revolution must be proletariat driven in order to surpass the bourgeoisie democratic revolution. In this sense, the revolution will be permanent.

\section{The Mis - Step}

In the Arab context, the term revolution should be used with relative caution. Not only were the prime makers (the masses) of the revolt denied access to power, but the new regimes that were subsequently inaugurated reflected sectional or sectarian interests. The elections in Tunisia in October 2011, opened the flood gate for the right - wing bloc which includes; Al Nahda - Renaissance Party (Brotherhood) and those who claim to be followers of Bourguiba (the fist Tunisian president). The responsibility to produce a new constitution for the country rested on this coalition. Although President Marzouki, a former leftist was oppose to the depose Ben Ali Regime, it would require a trade-off between his administration and the brotherhood for the country to move forward. This is particularly instructive given the fact that the revolutionary movement in Tunisia was not met to challenge the dependant pattern of development of the Ben Ali era. Rather the major criticism was leveled against the repressive police state structure and the opposition of the "royalties" on all economic activities which 
were under the direct control of the president's family. So far, the new ruling coalition has not modified fundamentally the pattern of development put in place by President Bourguiba. Instead, attempts have been made to infuse it with increased religious doses meant to placate alleged Islamic particularism.

In Egypt, following a presidential run-off, former President Mohammed Morsi was sworn into office on Jun $30^{\text {th }} 2012$ as the country's first democratic head of state. The Muslim brotherhood Freedom and Justice Party (FJP) worn 335 seats in the people assemble by fielding candidates for individual seats. The victory of the brotherhood raised the fear in the general public of the rise of political Islam that was deeply rooted in the echo of the slogan "Islamisation of society" Much of what happened in President Morsi's one year administration was a deliberate attempt by the president to grant himself sweeping powers, including the provision that all constitutional declarations, laws and decrees issued by him since he took office were "final and unchangeable". The fall of Morsi changed the mood from possibilities to inevitability. One notable exception to this, however, was in the brotherhood. The images of bloodshed and people dying (especially in the Tahrir square) across the country stood in stark contrast to the relatively lack of violence in the rebellion that ousted Mubarak from office. This contrast played a large role in building the broad support needed for military intervention. Timing was also a contributing factor, as the military took advantage of the waning popularity of the Morsi administration. Despite these examples, Morsi had his support based mostly with the brotherhood. This was, nonetheless, canceled out by the opposition of the National Salvation Front.

\section{At Issues}

Egypt is a heavy weight in the Middle East and it is often the fulcrum on which currents in the region turn. The fortunes of the Morsi Administration were squeezed between a public that was apprehensive of rigid application of the principle of Sharia and the political aspirations of the Muslim brotherhood (Morsi support base), who saw it as a veritable opportunity to right the wrongs that have been meted out to it for decades. Even the liberals and secular activists, who had earlier on split their votes between Mohammed Morsi and Ahmed Shafik during the run-off elections, despaired at finding themselves caught between the military and religious conservatives.

The transition to democracy in the wake of the Arab Spring has been anything but smooth. Though the level of crisis in Tunisia has been less that of Egypt, both countries have lurched from crisis to crisis. In the first two years after the spring, Egypt seems to break repeatedly into three camps: the military and other supporters of the Mubarak regime, the Muslim brotherhood (the Islamic party that has been officially banned but had nonetheless been the country's largest political force) and the young liberal, secular activists who set off the uprising. By the end of 2012, it appeared that the brotherhood had come out on top, as it worn control of parliament, and then the presidency, with Mohammed Morsi the leader of the group's political wing. Morsi then out maneuvered the military to the side lines and pushed through a constitution that was bitterly opposed both by the liberal groups and supporters of Mubarak regime.

At the close of the Morsi Administration, violent protests against the government were 
joined by chaos and street battles sparked initially by the handlings of death sentence from an earlier soccer riot. The administration imposed a state of emergency and the military warn against the "collapse of the state" (BBC, 2013). The situation in the country was not only complicated by the consummate protest against the activities of the president but also by the increasing economic woes of the masses that initially yearned for a change. The slim majority are Islamists hold going by the result of the last presidential elections run-off coupled with the vestiges of the old regime who is still wield significant economic populist capital, had commensurate impact on the crisis.

\section{A Mismanaged Course}

Through the years, events in Egypt and Tunisia have influenced one another to a considerable extent. Aside the fact that early nationalist movements in Egypt inspired Tunisians with a greater nationalist consciousness, the Arab Spring which was ignited in Tunisia had serious ramifications in Egypt. As with most newly independent nations in the $1950 \mathrm{~s}$, de-politicization of the society was a populist approach to the management of politics in the Arab world. Even existing socialist regime (like Nasser's) who took this approach, at least after the revolutionary phase, used it to consolidate their rules. However, the Nasser's regime was an amendment that adopted an elitist approach that excluded the popular classes from actively being involved in the management of society. Thus, the demand for a level playing field became the mantra of the alienated and a distinguishing feature of the behavior and attitude of the average Egyptian. The Egyptian state remained under aristocratic leadership until the ouster Mubarak (Amin, 2012).

No doubt, the Arab Spring was a product of indigent socio-economic conditions of a greater percentage of the population in the countries so affected. The momentous outburst of emotions that fueled the spring was symptomatic of state failure. Egypt and Tunisian are two states who could be conceived as candidates for accession to the group of emerging states, who, sadly enough, are not. Given the turf alluded to above; the stage was ripe for a revolution. Unfortunately, no sooner had the revolutionary process stated than the seeds from the elements that eventually hijacked the process sown. According to Trotsky (1931), in theory of Permanent Revolution, under developed countries must pass through two distinct revolutions: (a) the bourgeoisie democratic revolution (which socialist will assist) and (b) the socialist revolution (with an evolutional period of capitalist development). This is often referred to as the Theory of Stages (the Two Stages Theory or Stagism). Also, Lenin ( cited by Trotsky, 1983), in 1917 argued that the (Russian) bourgeoisie will not be able to carry through the task of the bourgeoisie of democratic revolution and therefore the proletariat had to take not only state power but also economic power. Lenin taught that a "A democratic dictatorship" of the workers and peasants would complete the task of the bourgeoisie. Trotsky, on the other hand, generalize his theory of Permanent Revolution by arguing that the proletariat needed to take power in a process of uninterrupted and Permanent Revolution in other to carry out the task of the bourgeoisie democratic revolution.

In the Arab Spring, there was neither a bourgeoisie democratic revolution nor a socialist revolution. What happened were general revolts borne out of a growing popular frustration akin to what happened in 1978, 1983 and 1984 in Tunisia and Egyptian mass strikes of 2007 / 
2008. There might have been variations in terms of intensity, but they were nowhere near the revolutions that took place in France in the $19^{\text {th }}$ Century, the Great October revolution in Russia in 1917, the 1949 Chinese Revolution and the 1959 Cuban Revolution respectively. Perhaps, the absence of a central figure to direct the course of the revolt partly exposes the fundamental flaws in the process. The fact the whole project was sporadic explained a major defect. To Marx, Permanent Revolution involves a revolutionary class which continued to push for, and achieve its interest despite the political dominance of actor with opposing interest (Marx, 1849). He also warned of attempts to "bribe the workers (masses) with a more or less disgusted forms of alms and to break their revolutionary strength by temporary rendering their situation tolerable" (Marx, 1850). Marx therefore recommended that the workers (masses):

\section{They must contribute most to their final victory, by informing themselves of their own class interests, by taking up their independent political position as soon as possible, by not allowing themselves to be misled by the hypocritical phrases of democratic petty bourgeoisie into doubting for one minute the necessity of an independently organized party of the proletariat. Their battle - cry must be: The Permanent Revolution (Marx, 1850: $9-I$ ).}

In a revolution, not only do the old brigades give way to a new one, the old institutions crumble and are subsequently replaced by new ones which are reflective of a new ideology. Instructively, the masses participate in the transformation of society to ensure that human values replace the values of the old elites. This process of deconstruction is also creation to the extent that the methods and passions used to pull down the ruins determines what kind of world arises from rubble. The struggles in the Middle East would not be complete by simply delivering concentrated political powers into the hands of new elites, who are more or less reflective of the old order, but by dispersing it. The changes effected by the Arab Spring should be representational and made to reflect new social and economic conditions. This will ultimately change the way people live and think in the Arab world.

\section{Conclusion}

The findings of this study suggest that the Arab Spring is an unfinished revolution. Premised on the fact that those who led the popular protests against authoritarian regimes in Egypt and Tunisia where not the beneficiaries. The goals of the social movement that fueled the upheavals in which governments in both country were replaced were not fully realized. In the two cases discussed in this paper, the social drivers of the process where: poor economic performance, unemployment (especially among uneducated youths), corruption and inequality. These are factors that could presage a revolutionary movement; an assessment that has since proven right with the fall of Ben Ali in Tunisia and Hosni Mubarak in Egypt respectively.

Although, fragmented outburst of social unrests were transformed into protests coordinated and sustained at the national front in Tunisia and Egypt, the coordinators of this 
movement did not use their autonomous organizations to push through a political programme which would require the dismantling of old institutions. Rather, the expectations of the revolutionary mass were hijacked by members of the elites who were either loyalties of the old order or those who used the opportunities to gain national prominence. The divergence nature of this outcome is such that, what would have ordinarily passed for a social revolution degenerated into what Trotsky called "Bourgeoisie democratic revolution". History is replete with the fact that the bourgeoisie class has not successfully carry out a social revolution against itself. That will amount to a class suicide. Therefore what was needed was for the masses to see through not only a political revolution but a social revolution that would guarantee the use of state power to take over economic power. This is the tangent of the never ending cycle of what is popularly known as Arab Spring.

\section{References}

Amin, S. (2012) The Arab Revolution: A Year After. Interface, a Journal for and About Social Movements, Vol. 4 no.1, pp.33 - 42

BBC(2013)Focus on Africa.Monitored by the Author on 23/04/2013,Time, 18:20pm

Engels, F. (1845) "Critical Battle Against the French Revolution ( Ch. VI. Part 3 x c)".the Holy Family, or Critique of Critical Criticism Against Bruno Bauer and Company. Translated by Richard Dixon and Clement Dults (1956).

Entelis, J.P. and Tessler, M.A. (1856) Republic of Tunisia in long, D.E. and Reich, B. (eds) The Government and politics of the Middle East and North Africa Colorado, Westview Press.

Hess, S. (2013) From the Arab Spring to the Chinese Winter: The Institutional Sources of Authoritarian Vulnerablity and Resilence in Egypt, Tunisia and China. International Political Science Review, vol. 34, no. 3, pp. 255

Knickmeyer, E. (2011) the Arab World's Youth Army. Foreign Policy, 27 January. Available at

http://www.foreignpolicy.com/articles/2011/01/27/the_arab_world_s_y outh_army. Accesses 05 March 2013

Levey, S. (2011) Fighting Corruption After the Arab Spring. Foreign Affairs, 16 June. Avauilableat : http://www.foreignaffairs.com/articles/67895/staurt-leve y/fighting-corruption-after-the-arab-spring. Accessed 07 may 2013

Long, D.E. and Reich, B. (2008) The Government and Politics of the Middle East and North Africa. London, Westview Press.

Marx, K, (1850) Address of the Central Committee to the Communist League.

Marx, K. (1849) "The Division of Labour in the KolruscheZeitung", NeueRheiruscheZeitung ( $2^{\text {nd }}$ ed.) (219).

Otthway, M. and Hamzawy, A. (2011) Protest Movements and Political Change in the Arab World. Carnegie Endowment for International Peace Policy Outlook, 28 January. Available at: http:://carnegieendowment.org/files/ottawaayhamzawy_Outlook_Jan11 
Transparency

_ProtestMovements.pdf. Accessed 15 ${ }^{\text {th }}$ March 2013.

International (2011) Corruption Perceptions Index: 2010 results. Available

http://www.transparency.org/policy_research/surveys_indices/cpi/2010 /results. Accessed $17^{\text {th }}$ May 2013.

Trotsky, L. (1931) '2. The Permanent Revolution is Not a 'Leap' by the proletariat, but the Reconstruction of the Nation under the leadership of the Proletariat." The permanent Revolution.

Trotsky, L. (1933) "Three Conceptions of the Russian Revolution".World Socialist Web.Site.International committee of the Fourth International.Retrieved, $3^{\text {rd }}$ June 2013..

World Bank (2012) World Development Indicators 2011. Available at: http://data.worldbank.org, accessed 30 ${ }^{\text {th }}$ May 2012 